\title{
Impact of metazooplankton on the composition and population dynamics of planktonic ciliates in a shallow, hypertrophic lake
}

\author{
Klaus Jürgens ${ }^{1, *}$, Oliver Skibbe ${ }^{2}$, Erik Jeppesen ${ }^{3}$ \\ ${ }^{1}$ Max Planck Institute of Limnology, PO Box 165, D-24302 Plön, Germany \\ ${ }^{2}$ Institute of Zoology, Free University of Berlin, D-14195 Berlin, Germany \\ ${ }^{3}$ National Environmental Research Institute, PO Box 314, DK-8600 Silkeborg, Denmark
}

\begin{abstract}
We conducted an enclosure study in Lake Søbygård, a shallow hypertrophic Danish lake, to examine the impact of metazooplankton on the structure of the microbial food web. Here we present results on ciliate abundance, species composition and trophic interactions during 2 consecutive stages of zooplankton succession. Over a $3 \mathrm{wk}$ period, metazooplankton shifted from dominance of rotifers to cyclopoid copepods and thereafter to cladocerans. On 2 different dates with contrasting zooplankton assemblages we performed enclosure experiments where we compared the population dynamics of ciliates in size-fractionated $(<50 \mu \mathrm{m})$ treatments with enclosures containing in situ densities of metazooplankton. The ciliate community in the lake and in the enclosures was mainly represented $1>80 \%$ of total abundance) by 3 small-sized taxa: Urotricha spp., Halteria grandinella and Rimostrombidium brachykinetum, which showed different dynamics in response to metazooplankton. In the first experiment, with dominance of rotifers, zooplankton had only a modest predatory impact on the ciliates, and interactions within the ciliate community were probably more important. Larger, raptorial ciliates (e.g. Monodinium sp., Lagynophrya sp.) seemed to have been the main predators of the small ciliates. Different species-specific responses of ciliates within the same size range were observed. In contrast, the second experiment, with dominance of crustacean zooplankton (cladocerans, copepods), demonstrated a clear top-down control of the whole ciliate community by metazooplankton. Predation is probably the dominating regulating mechanism for ciliate abundance, biomass and species composition in Lake Søbygård. In contrast, food limitation is thought to be of minor importance because of generally high concentrations of edible phytoplankton. This view was also supported in our experiments by very high net growth rates of the dominating ciliate species after predator removal (in the range 1.0 to $2.4 \mathrm{~d}^{-1}$ ). The study revealed 2 characteristics of hypertrophic lakes: first, zooplankton composition and the resulting predation pattern is the decisive factor for the protozoan community structure, and second, the ciliate community is dominated by high densities of a few small-sized species.
\end{abstract}

KEY WORDS: Ciliates - Zooplankton Microbial food web - Hypertrophic lake Predation - Rotifers · Copepods Cladocerans

\section{INTRODUCTION}

The classical grazer food chain and the microbial food web are linked by several direct and indirect interactions. Metazooplankton grazing is important for the recycling of nutrients and the production of dissolved organic substrates for bacteria (Lampert 1978) but it is also a controlling factor for the protozoan com-

•E-mail: juergens@mpil-ploen.mpg.de munity structure (Sanders \& Wickham 1993). The coupling between zooplankton and protists can have cascading effects on planktonic bacteria (Jürgens et al. 1994) and thus be an important structuring factor for the entire microbial food web. Due to their potential as grazers of small phytoplankton and bacteria and their role as food for various metazoans, ciliates are especially important links in pelagic food webs. Their grazing impact on pico- and nanoplankton has been demonstrated in marine studies (Sherr \& Sherr 1987) and more recently also in freshwater lakes (\$imek et 
al. 1995, Stabell 1996). The number of studies which have examined ciliate communities in the freshwater plankton has considerably increased in the last decade. However, our knowledge of the species composition, distribution and regulating factors of planktonic ciliates is still fragmentary.

The first comprehensive analysis of freshwater planktonic ciliate community structure was done by Beaver \& Crisman (1982). They described the shift in species composition in subtropical Florida lakes with increasing eutrophication, and assigned the orders Scuticociliatida, Oligotrichida, and Haptorida as the numerically most important ciliates. More recent studies in temperate European (Müller 1989, Müller et al. 1991, Laybourn-Parry \& Rogerson 1993) and North American lakes (Taylor \& Heynen 1987, Carrick et al. 1992) deviate from the observations of Beaver \& Crisman (1982). Small species from the orders Prostomatida and Oligotrichida were generally found to be the most abundant ciliate groups in temperate mesoeutrophic lakes.

Even less knowledge exists concerning the regulating mechanisms of planktonic ciliates, which show considerable seasonal dynamics with respect to species composition and abundance (e.g. Müller et al. 1991). Zooplankton predation, mainly by copepods, on ciliates is well documented in marine systems (see Stoecker \& Capuzzo 1990). The zooplankton-protozoan link in freshwater planktonic food webs has been examined recently and metazooplankton predation is an important controlling factor for the major protozoan groups (Carrick et al. 1991, Sanders \& Wickham 1993). Most metazooplankton groups can probably exert grazing pressure on ciliates; this has been demonstrated in laboratory experiments with cyclopoid copepods (Wickham 1995), calanoid copepods (Burns \& Gilbert 1993), cladocerans (Jack \& Gilbert 1993), and rotifers (Arndt 1993, Gilbert \& Jack 1993). Due to their different feeding modes, different species-specific effects of metazooplankton on natural ciliate communities could also be identified (Wiackowski et al. 1994, Wickham 1995). The degree to which ciliates are affected by predation or mechanical interference depends on their size and the existence of defence mechanisms ( Jack \& (iilbert 1997).

Eutrophic shallow lakes are especially suitable for studying trophic interactions due to a relatively simple food web structure, high process rates and mostly prevailing top-down control on plankton organisms (Jeppesen et al. 1997). These lakes are characterized by the dominance of few species which replace each other during the seasonal cycle and cause great oscillations in the whole pelagic ecosystem (Jeppesen et al. 1990). Field experiments using intact natural communities can help to identify the various direct and indi- rect effects of higher trophic levels on microbial populations and communities .

The goal of the present study was to examine the impact of different metazoan zooplankton communities on the major components of the microbial food web (ciliates, flagellates, bacteria). We used field enclosures in which zooplankton abundance and composition was manipulated by size-fractionation during 2 consecutive stages in the plankton succession of the shallow, hypertrophic Lake Søbygård. In this paper we report on the population dynamics of ciliates, at the community and the species level, in response to the changing metazooplankton composition. In a following paper (Jürgens \& Jeppesen unpubl.) we analyse the cascading effects of the food web structure on autotrophic and heterotrophic pico-and nanoplankton.

\section{METHODS}

Lake Søbygård. Lake Søbygård is a shallow, hypertrophic lake situated in central Jutland, Denmark $\left(56^{\circ} 15^{\prime} 20^{\prime \prime} \mathrm{N}, 9^{\circ} 48^{\prime} 35^{\prime \prime} \mathrm{E}\right)$. It is $0.38 \mathrm{~km}^{2}$ in area, with a mean depth of $1.0 \mathrm{~m}$ and maximum of $1.9 \mathrm{~m}$. The hydraulic retention time is on average 15 to $20 \mathrm{~d}$. Lake water is well mixed and thus without summer stratification. Submerged vegetation is sparse or absent. The average concentration of chlorophyll a during summer is between 130 and $730 \mathrm{\mu g} \mathrm{l}^{-1}$ (Jeppesen et al. 1990). This lake was intensively studied over the last $14 \mathrm{yr}$ and sediment-water interactions are described by Søndergaard et al. (1990), studies of the biological community are reported by Jeppesen et al. (1990, 1996, 1997, 1998), and Hansen \& Jeppesen (1992).

Enclosure experiments. During 2 consecutive periods in July/August 1994 mesocosm experiments were performed in Lake Søbygård. Six 5001 polyethylene enclosures ( $0.9 \mathrm{~m}$ in diameter, $0.7 \mathrm{~m}$ in depth), closed at the bottom and fixed to a wooden frame, were located close to the shore in the lake. Size-fractionated filtrations were applied in order to manipulate the zooplankton. All enclosures were first gently filled with water collected at a mid-lake station and filtered through a $50 \mu \mathrm{m}$ mesh in order to remove mesozooplankton. In 3 of the enclosures (further referred to as ' $+Z P^{\prime}$ ') zooplankton was reintroduced at approximately natural densities. Three of the enclosures were left without additional zooplankton (referred to as ' $<50^{\prime}$ ). In addition to these enclosures, three $10 \mathrm{l}$ glass bottles were filled with lake water filtered through a $10 \mu \mathrm{m}$ mesh, in order to remove microand mesozooplankton. These were incubated near the other enclosures in the lake (referred to as '<10'). The manipulated enclosures and bottles were sampled for 5 to $6 \mathrm{~d}$ in the lake; the first experiment was conducted 
from 6 to 11 July, the second experiment from 19 to 24 July 1994.

Sampling, chemical and biological analysis. Sampling of the enclosures for the microbial components (picoplankton, protozoans) was done once or twice daily during the experiments. Sampling for the chemical analysis and the determination of zooplankton abundance and species composition was done at the beginning and end of the experiments. Chemical analysis was performed according to standard methods (see Søndergaard et al. 1990); chlorophyll a was determined spectrophotometrically after extraction with ethanol according to Holm-Hansen \& Riemann (1978). For zooplankton, 2 l samples were filtered through a $40 \mu \mathrm{m}$ net, then fixed in Lugol. Ciliates and rotifers were counted and sized from Lugol's fixed samples using settling chambers and an inverted microscope. Selected samples for identification of ciliates to genus- or species-level were post-fixed with Bouin's fixative and impregnated with Protargol according to the quantitative technique of Montagnes \& Lynn (1987), modified by Skibbe (1994). Dominant ciliate species could be related from Protargol-stained preparations to Lugol's fixed samples which were used for the quantification. Parallel to the sampling of the enclosures, water samples were taken from a mid-lake station (1.5 $\mathrm{m}$ depth) with a core sampler covering the upper $1 \mathrm{~m}$ of the water column.

Data analysis. We analysed all data of an experiment by using measurements of the same variable (ciliate taxa or group of organisms such as small and large ciliates, rotifers) within the same enclosure at different times (repeated-measures ANOVA). We compared the development of organisms between the treatment with zooplankton to those where zooplankton was removed $(<50,<10)$. Data were log-transformed before ANOVA to stabilize variances. ANOVAs were performed using the software package STATISTICA 5.1. Due to multiple simultaneous tests of the different organisms, a sequential Bonferroni test procedure (Rice 1989) was performed. The initial critical probability value was set at $\mathrm{p}<0.05 / \mathrm{n}$, where $\mathrm{n}=$ number of tests per experiment (11 or 12 , respectively). Net growth rates of the dominant ciliate taxa were calculated for intervals where population abundance increased for more than 2 sampling dates and by taking the slope of the regression of cell number (natural logarithm) versus time.

\section{RESULTS}

The enclosure experiments were performed during a period of warm and stable weather conditions with water temperatures of 20 to $25^{\circ} \mathrm{C}$. The design of our size-fractionations (first filtering all enclosures through a $50 \mu \mathrm{m}$ mesh, then refilling zooplankton in the $+\mathrm{ZP}$ treatments) proved to be adequate for this situation as it did not strongly alter the chemical conditions or the phytoplankton community compared to the lake (Table 1). Significant changes occurred within the phytoplankton assemblage during the study period, with a strong increase in all dominant algae during the time of the first experiment and a shift in species composition from the first to the second experiment. The

Table 1. Physico-chemical conditions (TP: total phosphorus; TN: total nitrogen), chlorophyll a and particulate organic carbon (POC) in the enclosures and in the lake during the 2 experiments. Values for the enclosures are mean values of the 3 replicate treatments (mean $\mathrm{CV}=9.4 \%$ ); values for the lake are mean values of duplicate measurements. nd: not determined

\begin{tabular}{|c|c|c|c|c|c|c|c|c|}
\hline & $\mathrm{PO}_{4}-\mathrm{P}$ & TP & $\begin{array}{r}\mathrm{NH}_{4}-\mathrm{N} \\
-\mathrm{m}\end{array}$ & $\mathrm{NO}_{3}-\mathrm{N}$ & $\mathrm{TN}$ & POC & $\begin{array}{c}\text { Chl } a \\
\left(\mu \mathrm{g} \mathrm{l}^{-1}\right)\end{array}$ & $\begin{array}{l}\text { Temp. } \\
\left({ }^{\circ} \mathrm{C}\right)\end{array}$ \\
\hline Expt 1 (July 7) & & & & & & & & $19.5-22.8$ \\
\hline$<50,+Z P$ & 0.87 & 1.02 & 0.30 & 0.48 & 1.95 & 3.44 & 31.3 & \\
\hline$<50$ & 0.87 & 1.10 & 0.24 & 0.50 & 1.80 & 4.09 & 34.9 & \\
\hline$<10$ & 0.82 & 0.97 & 0.21 & 0.51 & 1.75 & 4.35 & 28.5 & \\
\hline Lake & 0.98 & 1.14 & 0.58 & 0.43 & 2.30 & 3.21 & 26.0 & \\
\hline \multicolumn{9}{|l|}{ Expt 1 (July 11 ) } \\
\hline$<50,+Z P$ & 0.25 & 0.73 & 0.01 & 0.00 & 1.57 & 9.81 & 38.3 & \\
\hline$<50$ & 0.26 & 0.68 & 0.00 & 0.00 & 1.52 & 9.21 & 41.3 & \\
\hline$<10$ & 0.13 & 0.96 & 0.02 & 0.00 & 1.84 & 13.54 & 55.7 & \\
\hline Lake & 0.63 & 0.96 & 0.01 & 0.00 & 2.10 & 9.78 & 219.0 & \\
\hline Expt 2 (July 19) & & & & & & & & $21.2-25.2$ \\
\hline$<50,+Z P$ & 0.61 & 1.02 & 0.01 & 0.00 & 2.70 & 10.61 & 139.0 & \\
\hline$<50$ & 0.61 & 0.95 & 0.00 & 0.00 & 1.80 & 11.05 & 134.2 & \\
\hline$<10$ & 0.62 & 0.93 & 0.00 & 0.00 & 1.70 & 9.88 & 120.8 & \\
\hline Lake & nd & nd & nd & $n d$ & nd & nd & 196.5 & \\
\hline
\end{tabular}


dominating algae during the first experiment were Actinastrum sp., Monoraphidium sp, Scenedesmus spp., Pediastrum sp. and several species of cryptomonads. Procaryotic and eucaryotic picoalgae increased during the course of the first experiment (Synechococcus spp. and Chlorella spp., both $>10^{5}$ cells ml-1). During the second experiment the phytoplankton assemblage was dominated by a bloom of Scenedesmus spp. (mainly $S$. quadricauda and $S$. acuminata, coenobia and single cells). The increase in phytoplankton, which was much more pronounced in the lake than in the enclosures, was probably the reason for the depletion in ammonium and nitrate below the detection limit whereas $\mathrm{P}$ concentrations remained at a high level (Table 1).

\section{Zooplankton dynamics}

During our experiments, 2 consecutive stages in the zooplankton succession occurred in Lake Søbygård. The beginning of the first experiment was characterized by the dominance of rotifers, with a large contribution of Brachionus species (mainly B. calyciflorus), Keratella quadrata and Asplanchna spp. (Table 2). The situation was already in a transient state and rotifer populations in the lake were declining strongly. Keratella spp. had disappeared totally by the end of the experiment, and Brachionus spp. decreased to less than $5 \%$ of its former values. Only Asplanchna spp. remained at high levels and became the dominant rotifer species at the end of that week (Table 2). One reason for the rotifer collapse under relatively stable food conditions was exposure to predation by Asplanchna spp. and Cyclops vicinus. In addition, Brachionus spp. was heavily infected by microsporidians (probably Plistophora asperospora, H. Holst, University of Hamburg, pers. comm.) which are known to cause mortality of planktonic rotifers (Ruttner-Kolisko 1977). The only zooplankton which increased during the course of the first experiment were cyclopoid copepods (mainly C. vicinus).

One week later, at the start of the second experiment, zooplankton composition was dominated by cyclopnid copenods artult and copepodite stages of Cyclops vicinus) and daphnids. Daphnia spp. increased further towards the end of the experiment (Table 2) and were then, in terms of biomass, the dominating zooplankton group. Rotifers remained in low numbers during the second experiment. In summary, contrasting zooplankton compositions prevailed during the 2 experiments: the first experiment can be characterized as microzooplankton-dominated with high numbers of rotifers, whereas the second experiment was a mesozooplankton-dominated community with high numbers of $C$. vicinus and Daphnia spp. However, during both experiments zooplankton shifted in species composition, in the lake as well as in the enclosures: first from rotifers to $C$. vicinus dominance, and second, from $C$. vicinus to Daphnia spp. dominance.

The manipulation of the metazooplankton community by our size-fractionation design proved to be successful and in both experiments we obtained manipulated treatments virtually without any metazooplankton $(<10 \mu \mathrm{m})$ or without crustacean zooplankton and brachionids $(<50 \mu \mathrm{m})$. Also, the treatment designed to result in a comparable composition of zooplankton to the lake $(+\mathrm{ZP})$ worked well, with a modest reduction (Expt 1) or increase (Expt 2) in zooplankton abundance compared to the lake. However, due to the strong dynamics inherent in the lake zooplankton community, the situation also changed in the enclosures (Fig. 1). In the tirst experiment smail rotifers (mainly Filinia sp.) increased in the zooplankton-free enclosures $(<50)$. In the $+\mathrm{ZP}$ enclosures, a collapse of

Table 2. Zooplankton composition and abundance (ind. $1^{-1}$ ) in Lake Søbygård at the start and end of the 2 enclosure experiments

\begin{tabular}{|c|c|c|c|c|}
\hline \multirow[t]{2}{*}{ Zooplankton } & \multicolumn{2}{|c|}{ Expt 1} & \multicolumn{2}{|c|}{ Expt 2} \\
\hline & 7 July & 11 July & 19 July & 24 July \\
\hline Cyclops vicinus & 5.7 & 12.9 & 28.6 & 1.8 \\
\hline Eucyclops serrulatus & 1.1 & 0.3 & 0 & 1.8 \\
\hline Cyclopoid copepodites & 29.7 & 55.2 & 290.5 & 86.0 \\
\hline Cyclopoid nauplii & 63.5 & 121.6 & 461.9 & 164.9 \\
\hline Total copepods & 99.7 & 190.0 & 781.0 & 254.4 \\
\hline Daphnia spp. & 0.5 & 4.6 & 109.5 & 203.5 \\
\hline Ceriodaphnia spp. & 0 & 0.2 & 0 & 0 \\
\hline Bosmina longirostris & 0 & 0 & 2.4 & 5.3 \\
\hline Alona spp. & 3.8 & 0 & 0 & 5.3 \\
\hline Chydorus spp. & 1.7 & 4.1 & 9.5 & 1.8 \\
\hline Pleuroxus uncinatus & 2.7 & 0 & 0 & 7.0 \\
\hline Total cladocerans & 8.8 & 8.7 & 121.4 & 222.8 \\
\hline Brachionus calyciflorus & 5843.2 & 124.6 & 0.0 & 0.0 \\
\hline B. budapest & 462.9 & 0.0 & 0.0 & 0.0 \\
\hline B. rubens & 587.3 & 0.0 & 0.0 & 8.8 \\
\hline B. angularis & 98.7 & 32.5 & 0.0 & 54.6 \\
\hline B. urceolaris & 0.0 & 0.0 & 0.0 & 5.3 \\
\hline Keratella quadrata & 2421.7 & 0.0 & 0.0 & 0.0 \\
\hline K. cochlearis & 19.7 & 0.0 & 0.0 & 0.0 \\
\hline Filinia longiseta & 47.6 & 27.0 & 26.2 & 54.6 \\
\hline F. cornuta brachiata & 209.8 & 27.8 & 0.0 & 0.0 \\
\hline Synchaeta spp. & 7.9 & 27.8 & 0.0 & 0.0 \\
\hline Polyarthra spp. & 531.6 & 484.4 & 169.2 & 1.8 \\
\hline Euchlanis spp. & 7.9 & 0.0 & 0.0 & 0.0 \\
\hline Trichocerca pusilla & 9.8 & 0.0 & 0.0 & 0.0 \\
\hline Asplanchna priodonta & 119.0 & 120.6 & 0.0 & 0.0 \\
\hline A. girodi & 666.7 & 482.5 & 52.4 & 1.8 \\
\hline Total rotifers & 11034.0 & 1327.3 & 247.7 & 126.7 \\
\hline
\end{tabular}


the Brachionus population and an increase of copepods occurred, which is similar to the situation in the lake. This resulted in a somehow reversed situation in which the $<50$ enclosures achieved a higher density of rotifers at the end of the experiments than the $+\mathrm{ZP}$ enclosures. In the second experiment, where large crustacean zooplankton dominated, a clearer difference between $<50$ and $+Z$ P enclosures occurred. The $+Z P$ treatments showed a shift from copepods to cladocerans (virtually Cyclops vicinus to Daphnia spp.) which corresponded to the shift in the lake but in higher abundance. The $<50$ enclosures developed only moderate densities of rotifers whereas mesozooplankton remained virtually absent (Fig. 1).

\section{Ciliate species composition}

Total ciliate abundance in the lake was within the range of 100 to 600 cells $\mathrm{ml}^{-1}$ during the first experimental period and 30 to 100 cells $\mathrm{ml}^{-1}$ during the second experiment. The ciliate community was dominated by typical planktonic species (see Foissner 1994). Altogether 22 taxa were identified from Protargol-stained samples (Table 3). The dominating species occurred in both experiments and all treatments but in different proportions. In the lake and in the experimental enclosures, ciliates were dominated by small prostomatids (Urotricha spp.) and small oligotrichs (Halteria spp., Strobilidium spp.).

We tried to determine the dominant species by assessing relevant taxonomic features from Protargol impregnations (Fig. 2). There were several small Urotricha species that were very common during the entire study period. The majority were probably $U$. furcata (Fig. 2A) and $U$. farcta. However, they could not quantitatively be distinguished because the only reliable criterion seems to be the second caudalcilium in $U$. furcata (Foissner et al. 1994), which was not always clearly visible. Therefore we lumped these 2 species (and possibly other small species of this genus) together as Urotricha spp. The other small prostomatid of temperate lakes, Balanion planctonicum (Müller 1991), was not found in our samples. The oligotrich Halteria sp., which occurred in considerable numbers
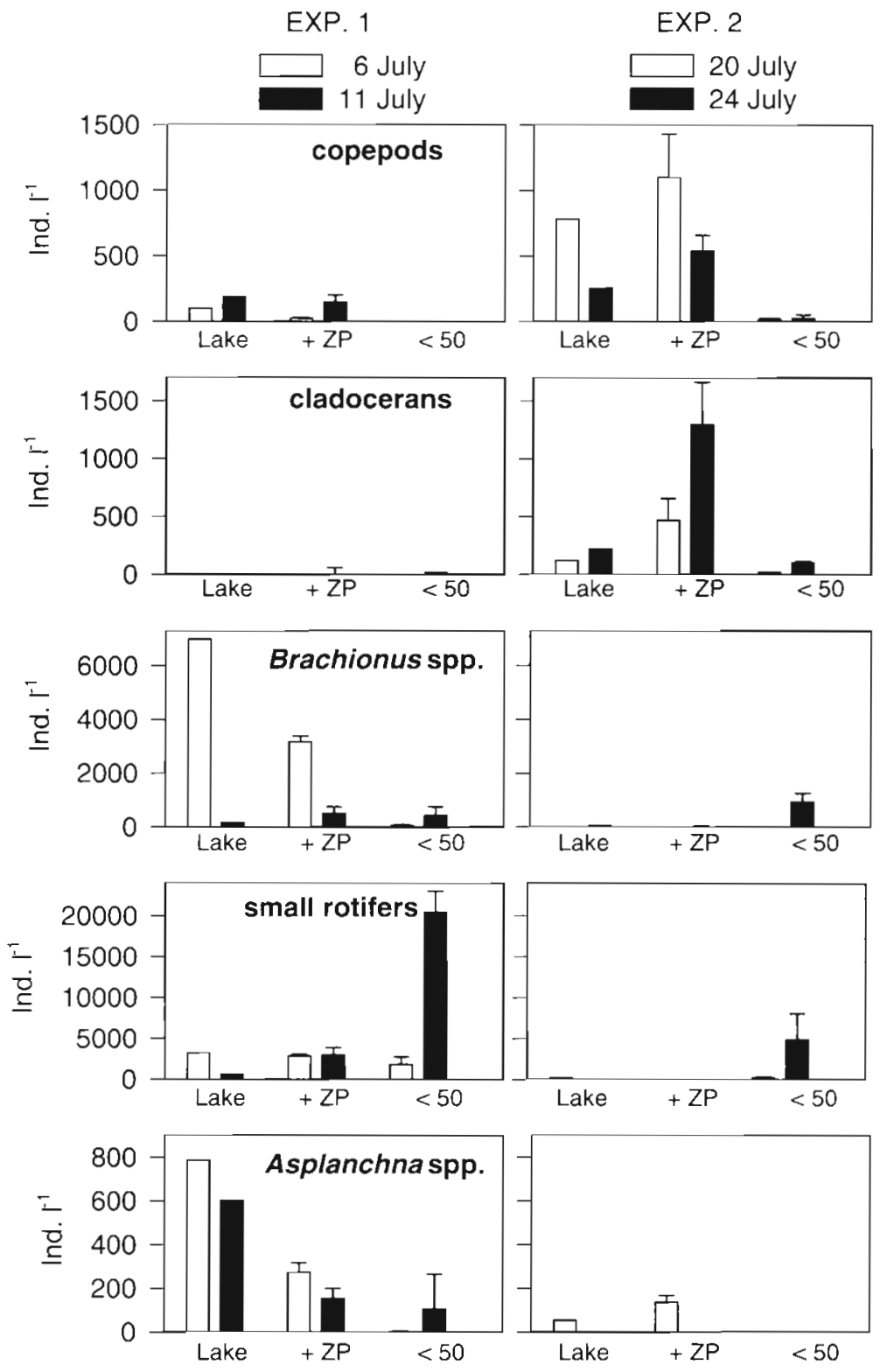

Fig. 1. Initial and final abundances of metazoan zooplankton in the mesocosms and in Lake Søbygård

in the experiments, closely resembles the descriptions of $H$. grandinella (Foissner et al. 1991), a widely distributed and common species in freshwater plankton (Foissner 1994, Simek et al. 1995). The other abundant oligotrich was a small Strobilidium sp., characterized by 6 somatic kinetids and a body length of 15 to $20 \mu \mathrm{m}$. This species, whose morphology was consistent among individuals (Fig. 2C), occurred in high numbers especially during the first experiment. It seems to be the same species (K. Simek pers. comm.) which has been described and quantified in Rimov Reservoir by Simek et al. (1995) under the name Strobilidium hexakine- 
tum. However, no proper original description of $S$. hexakinetum exists and the same species was later described by Krainer (1995) under the name Rimostrombidium brachykinetum (Foissner pers. comm.). We refer to the name proposed by Krainer (1995) because we think that this species can clearly be identified from Protargol impregnations. However, we are aware that there is some controversy in the literature concerning the nomenclature of strobiliid ciliates and whether one should use the genera name Rimostrombidium or Strobilidium (Petz \& Foissner 1992, Foissner 1994, Montagnes \& Lynn 1991).

During the first experiment the 3 taxa Urotricha spp., Halteria grandinella and Rimostrombidium brachykinetum always comprised $>90 \%$ and during the second

Table 3. List of ciliate taxa determined from Protargol impregnations. Size range (max. dimensions) as determined from Lugol-fixed samples

\begin{tabular}{|lc|}
\hline Ciliate taxon & Size $(\mu \mathrm{m})$ \\
\hline Prostomatida & \\
Urotricha sp. 1 (furcata/farcta) & $12-18$ \\
Urotricha sp. 2 (c.f. pelagica) & $35-60$ \\
& \\
Oligotrichida & \\
Rimostrombidium brachykinetum & $15-19$ \\
Strobilidium lacustris & $50-55$ \\
Strombidium viride & $35-50$ \\
Halteria grandinella & $17-25$ \\
& \\
Haptorida & \\
Askenasia sp. & $25-32$ \\
Monodinium spp. & $35-55$ \\
Lagynophrya sp. & $32-50$ \\
Paradileptus elephantinus & $100-160$ \\
Actinobolina sp. & $55-70$ \\
Enchelys sp. & $45-55$ \\
Scuticociliatida & \\
Cyclidium sp. & \\
Cinetochilum margaritaceum & $15-25$ \\
Pleuronema sp. & $20-30$ \\
& $50-60$ \\
Peritrichida & \\
Vorticella spp. & \\
Vorticella meyeri & \\
Colpodea & \\
Cyrtolophosis mucicola & \\
Pleurostomatida & $20-25$ \\
Litonotus sp. & $25-30$ \\
Amphileptus sp. & \\
Cyrtophorida & \\
Chilodonella sp. & \\
Hypotrichia & \\
Oxytricha sp. & \\
\hline
\end{tabular}

experiment $>80 \%$ of total ciliate abundance. During the second experiment scuticociliates (Cyclidium spp., Cinetochilum margaritaceum) and Cyrtolophosis mucicola also developed in higher numbers (up to $20 \mathrm{ml}^{-1}$ ) in the $<50$ enclosures.

Within the larger sized ciliate taxa, only haptorids increased in abundance and reached higher cell numbers in the experimental treatments when metazooplankton were reduced. The most abundant of these predatory ciliates, reaching numbers of up to 20-30 $\mathrm{ml}^{-1}$ in the zooplankton-free enclosures, were Monodinum sp. and Lagynophrya acuminata (Fig. 2A,D). The latter resembled the species described by Wilbert (1986) and Foissner et al. (1995). Monodinium sp. were present with 1 or 2 ciliary bands; the latter are cells in division and might be confused with a small Didinium. However, within a larger Didinium population there are always some dividing cells with 4 ciliary bands (Skibbe unpubl. obs.) but this was not the case in our samples. Other predatory ciliates which frequently occurred were Askenasia sp., Urotricha pelagica and Paradileptus elephantinus.

\section{Zooplankton-ciliate interactions}

The development of the 3 dominant ciliate taxa in the lake and in the enclosures is shown for the 2 experimental periods in Figs. 3 \& 4. For the first experiment (Fig. 3) large (predatory) ciliates and rotifers are also shown, for the second experiment (Fig. 4) large ciliates and other small ciliates (mainly scuticociliates and Cyrtolophosis mucicola) were included. Great differences occurred in the population development for the different ciliate species between experiments and treatments. The population dynamics in the enclosures with zooplankton (+ZP) closely resembled in both experiments the development in the lake, thus indicating that our treatment did not strongly alter the natural conditions. In contrast, the $<50$ and $<10$ enclosures exhibited deviating population developments for some of the respective ciliate species; we interpreted this mainly as a result of altered zooplankton composition. Results of statistical tests for comparison of the enclosures $<50$ and $<10$ with $+\mathrm{ZP}$ are shown in Table 4 .

The repeated-measure ANOVAs revealed whether there are significant changes during time and between the treatments with and without zooplankton. This and the illustration of the general population developments (Figs. $3 \& 4$ ) demonstrate that the removal of metazooplankton $>50 \mu \mathrm{m}$ had different effects in the 2 experiments: in the first experiment there was a reduction and in the second one an increase in the population development of small ciliates relative to the controls $(+\mathrm{ZP})$. In the first experiment the $<50 \mu \mathrm{m}$-filtration 


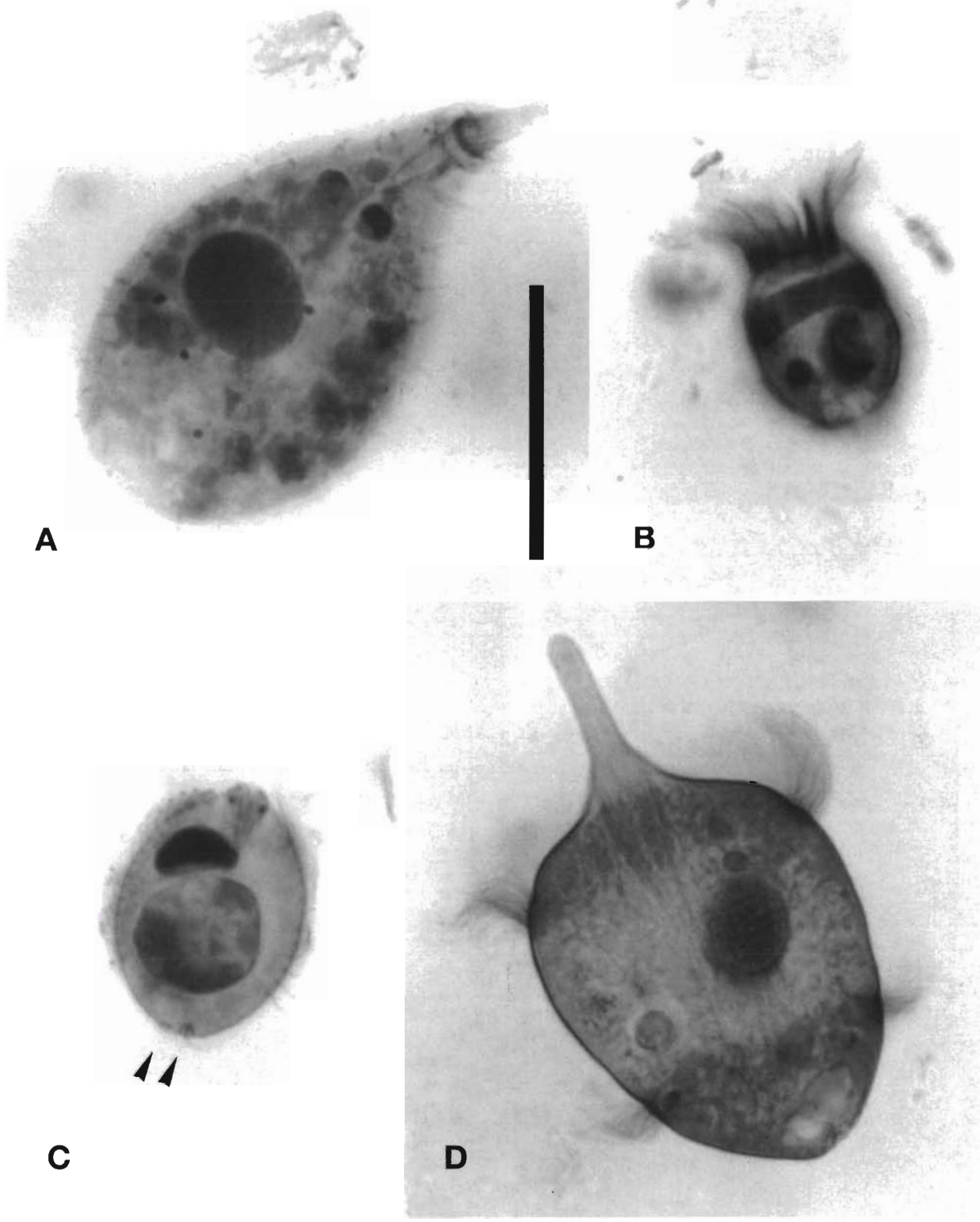

Fig. 2. Microphotographs of Protargol impregnations of some dominating ciliate species during the experiments. (A) Lagynophrya acuminata; (B) Rimostrombidium brachykinetum; (C) Urotricha furcata, arrows point to the 2 basal bodies of the caudal cilia; (D) Monodinium sp. Scale bar $=20 \mu \mathrm{m}$ 

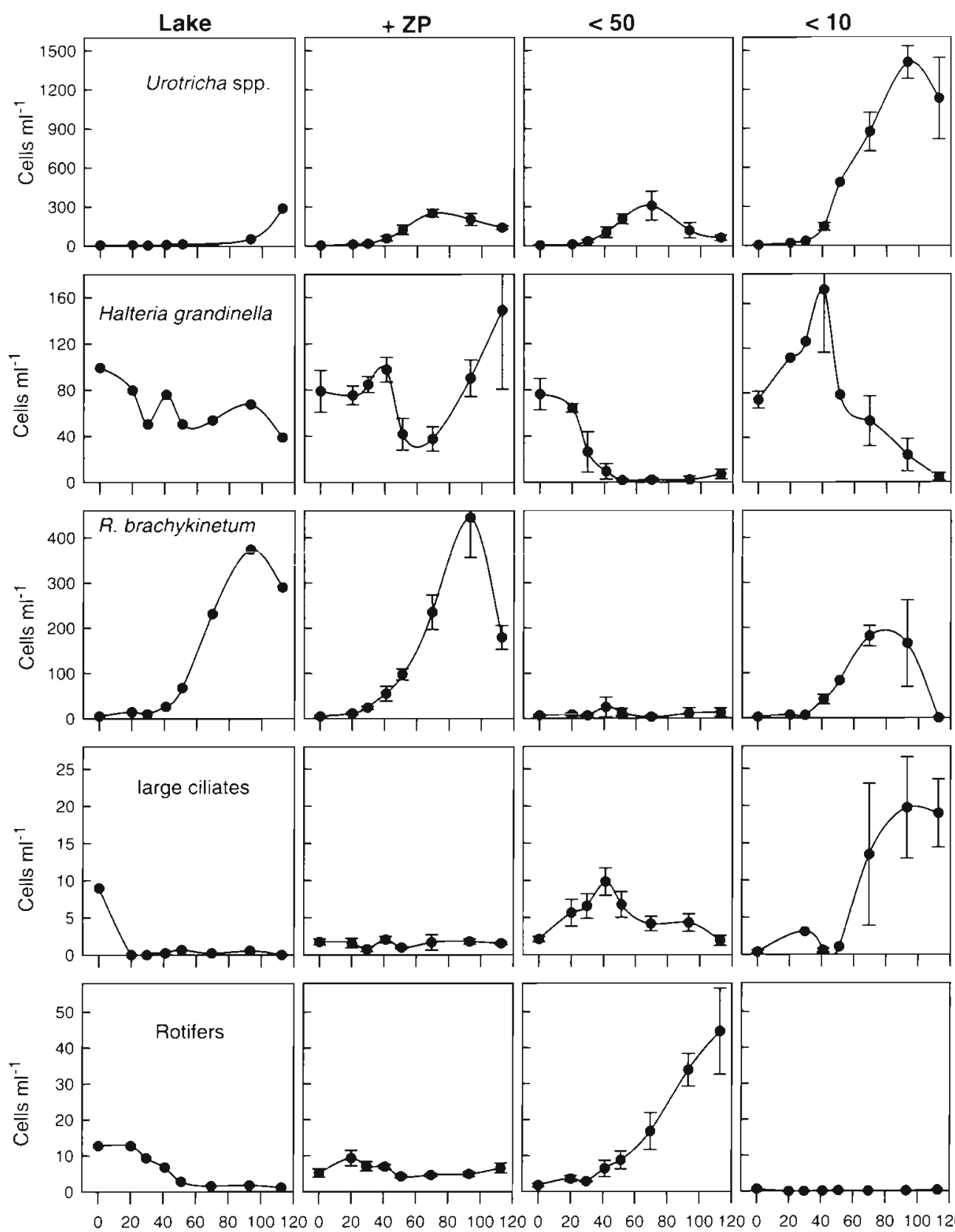

Time (h)

Fig. 3. Expt 1: population dynamics of the 3 dominating small ciliate species, total large ciliates and rotifers in the mesocosms (mean and standard deviation of the 3 replicate enclosures) and in the lake

removed cyclopoid copepods and strongly reduced the larger rotifers (Brachionus spp., Asplanchna spp.) (Fig. 1). For the 3 dominant ciliates, this resulted in either no (Urotricha) or negative (Halteria, Rimostrombidium) effects with strong declines compared to the zooplankton treatment. Possible predators on the small ciliates were rotifers and large, predatory ciliates which developed in the $<50 \mu \mathrm{m}$ fraction. The main species of ciliates in this group were the Haptorids Lagynophrya sp. and Monodinium sp., and the main rotifers were Filinia sp. and Polyarthra sp. The $<10 \mu \mathrm{m}-$ filtration resulted first in an increase of all ciliate species, but towards the end of the experiment small species decreased again, parallel to the maximum of large, predatory ciliates. Although in maximum dimensions far larger than the net mesh size, some of these preda- 

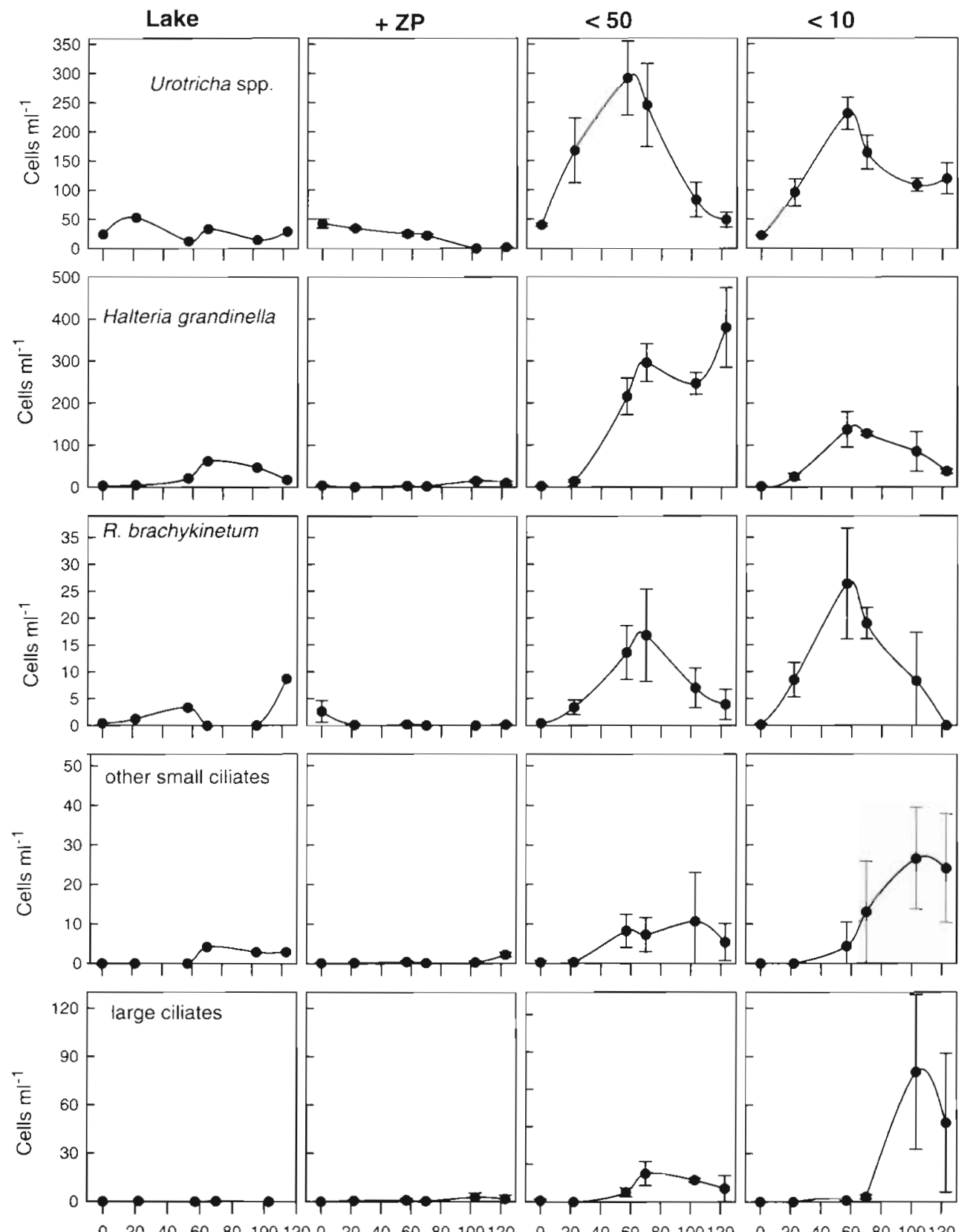

Time $(\mathrm{h})$

Fig. 4. Expt 2: population dynamics of the 3 dominating small ciliate species, large, predatory ciliates and other small ciliates (mainly Cyclidium spp., Cinetochilum margaritaceum and Cyrtolophosis mucicola) in the mesocosms (mean and standard deviation of the 3 replicate enclosures) and in the lake

tory ciliates can also pass through a $10 \mu \mathrm{m}$ mesh and then rapidly increase in abundance.

The $<50 \mu \mathrm{m}$ fractionation in the second experiment, where crustacean zooplankton dominated, eliminated most of the metazooplankton and only rotifers ( $\mathrm{Bra}$ chionus spp. and Polyarthra spp.) appeared in moderate densities in these treatments (Fig. 1). The removal of mesozooplankton had a clear positive effect on all ciliate taxa which showed a strong and immediate response after zooplankton removal. In addition to the 3 major ciliate taxa, Scuticociliates (mainly Cyclidium spp., Cinetochilum marganitaceum) and Cyrtolophosis mucicola also developed in higher abundance. Large, predatory ciliates (mainly Lagynophrya sp.) developed more towards the end of the experiment, again paralleled by a decrease in small ciliates. 
From the population increases in the treatments without or with reduced metazoan predators $(<10,<50)$ we calculated the net growth rates of the dominant ciliate taxa (Table 5). The values are within the range 1 to $2.35 \mathrm{~d}^{-1}$ (doubling times 7 to $17 \mathrm{~h}$ ). These high growth rates could be found for the 3 dominating small ciliate taxa and also for the larger raptorial species Monodinium sp. and Lagynophrya sp.

\section{DISCUSSION}

Typical for hypertrophic lakes are the dominance of a few species which occur in high abundance, and large oscillations in the biological structure due to reduced homeostatic mechanisms within the plankton community when compared to oligo- and mesotrophic lakes (Jeppesen et al. 1990, Sommaruga \& Robarts 1997). In Lake Søbygård strong fluctuations occur in the plankton community structure over short time scales, which can often be related to changes in fish predation pressure and cascading effects at lower trophic levels (Jeppesen et al. 1990, 1996). Increased fish predation results, for example, in a shift from Daphnia to Bosmina and copepods, and at even higher fish predation to dominance of rotifers and cyclopoid copepods (Jeppesen et al. 1990, 1998). Productivity in Lake Søbygård is extremely high and densities of phyto- and zooplankton are among the highest reported in the literature. Chlorophyll a levels regularly reached maxima of $>500 \mu \mathrm{g} \mathrm{l}^{-1}$ and summer means of zooplankton biomass (consisting mainly of rotifers, cyclopoids, Bosmina longirostris and Daphnia hyalina) are within the range 0.5 to $1.2 \mathrm{mg} \mathrm{Cl}^{-1}$ (Jeppesen et al. 1998). Although the lake now has reduced nutrient loading, it is still hypertrophic, and it is no surorise that ciliate concentrations proved to be among the highest reported in the literature.

The field situation examined during our enclosure experiments represented a typical summer situation for Lake Søbygård. A comparable zooplankton succession, with a shift from rotifers (mainly brachionids) to copepods and cladocerans, has been reported from previous years (Jeppesen et al. 1990). Lake Søbygård is one of the few examples where rotifers achieve sufficiently high numbers to produce a phytoplankton collapse and a clear-water phase (Jeppesen et al. 1990).
Table 4. Summary of the effects of zooplankton manipulation on the abundance of ciliates and rotifers. Results of ANOVA with repeated measure, in comparison to zooplankton treatments $(+Z P)$. Data from all dates during the experiments were used. Reported levels of significance ( $p$ values) correspond to the univariate between-subject effect. $\uparrow$ and $\downarrow$ denote whether the fractionation significantly increased or decreased the mean population density, respectively. Significance was judged according to the sequential Bonferroni procedure, with an initial critical probability value of $p<0.0045$ (11 non-independent tests, Expt 1 ) or $p<0.0042$ (12 non-independent tests, Expt 2), respectively. nt: not tested due to low abundance

\begin{tabular}{|c|c|c|c|c|}
\hline Variable & $\begin{array}{r}\text { Ex } \\
<50 \mu \mathrm{m}\end{array}$ & $\begin{array}{l}\text { pt } 1 \\
<10 \mu \mathrm{m}\end{array}$ & $\begin{array}{r}\text { Exp } \\
<50 \mu \mathrm{m}\end{array}$ & $<10 \mu \mathrm{m}$ \\
\hline Urotricha spp. & & $\uparrow$ & $\uparrow$ & $\uparrow$ \\
\hline Zooplankton & 0.8818 & 0.0006 & 0.0002 & 0.0002 \\
\hline Time & 0.0000 & 0.0000 & 0.0000 & 0.0000 \\
\hline Zooplankton $\times$ Time & 0.3045 & 0.0069 & 0.0000 & 0.0000 \\
\hline Halteria grandinella & & & $\uparrow$ & $\uparrow$ \\
\hline Zooplankton & 0.0260 & 0.0283 & 0.0000 & 0.0000 \\
\hline Time & 0.0000 & 0.0000 & 0.0000 & 0.0000 \\
\hline Zooplankton $\times$ Time & 0.0001 & 0.0000 & 0.0000 & 0.0000 \\
\hline Rimostrombidium brachykinetum & $\downarrow$ & & $\uparrow$ & $\uparrow$ \\
\hline Zooplankton & 0.0065 & 0.047 & 0.0001 & 0.0025 \\
\hline Time & 0.0290 & 0.0000 & 0.2058 & 0.0020 \\
\hline Zooplankton $\times$ Time & 0.0001 & 0.0000 & 0.0002 & 0.0001 \\
\hline Other small ciliates & & & $\uparrow$ & $\uparrow$ \\
\hline Zooplankton & nt & $\mathrm{nt}$ & 0.0021 & 0.0077 \\
\hline Time & nt & $\mathrm{nt}$ & 0.0001 & 0.0000 \\
\hline Zooplankton $\times$ Time & nt & $\mathrm{nt}$ & 0.0394 & 0.0021 \\
\hline Total small ciliates & $\downarrow$ & $\uparrow$ & $\uparrow$ & $\uparrow$ \\
\hline Zooplankton & 0.0030 & 0.0006 & 0.0000 & 0.0000 \\
\hline Time & 0.0000 & 0.0000 & 0.0000 & 0.0000 \\
\hline Zooplankton $\times$ Time & 0.0000 & 0.0060 & 0.0000 & 0.0000 \\
\hline Large ciliates & $\uparrow$ & & $\uparrow$ & $\uparrow$ \\
\hline Zooplankton & 0.0013 & 0.4705 & 0.0224 & 0.0009 \\
\hline Time & 0.0008 & 0.0000 & 0.0161 & 0.0000 \\
\hline Zooplankton $\times$ Time & 0.0000 & 0.0000 & 0.2608 & 0.0290 \\
\hline \multicolumn{5}{|l|}{ Rotifers } \\
\hline Zooplankton & 0.0385 & nt & nt & nt \\
\hline Time & 0.0000 & nt & $\mathrm{nt}$ & $\mathrm{nt}$ \\
\hline Zooplankton $\times$ Time & 0.0000 & nt & nt & $\mathrm{nt}$ \\
\hline
\end{tabular}

Our experimental study covered the following successional sequences: (1) final stage of a rotifer-induced phytoplankton depression with the dominance of picoplanktonic algae; (2) collapse of the rotifer population probably due to predation and parasitism, strong population growth of Cyclops vicinus; (3) phytoplankton bloom (mainly Scenedesmus) and population maxima of cyclopoid copepods; (4) population increase of Daphnia spp.

The last stage, which was not entirely covered by our experiments, would probably have resulted in the next phytoplankton depression and clear-water phase due to a large Daphnia population (Jeppesen et al. 1990). 
Table 5. Maximum abundances of the dominant ciliate species in Lake Sabygard and in the 2 enclosure experiments (mean \pm SD of 3 replicate enclosures). Maximum net growth rates are calculated from the population increase in the enclosures (mean $\pm \mathrm{SD}$ of 3 replicates)

\begin{tabular}{|c|c|c|c|c|c|}
\hline \multirow[t]{2}{*}{ Ciliate taxon } & \multicolumn{3}{|c|}{ Max abundance $\left(\mathrm{ml}^{-1}\right)$} & \multicolumn{2}{|c|}{ Max. net growth rate $\left(d^{-1}\right)$} \\
\hline & Lake & $\begin{array}{c}\text { Enclosure } \\
\text { Expt } 1\end{array}$ & $\begin{array}{l}\text { Enclosure } \\
\text { Expt } 2\end{array}$ & Expt 1 & Expt 2 \\
\hline Urotricha spp. (furcata/farcta) & 288 & $1406 \pm 125$ & $292 \pm 63$ & $2.24 \pm 0.11$ & $1.00 \pm 0.16$ \\
\hline Rimostrombidium brachykinetum & 374 & $445 \pm 88$ & $17 \pm 9$ & $1.52 \pm 0.32$ & $1.51 \pm 0.33$ \\
\hline Halteria grandinella & 99 & $170 \pm 71$ & $380 \pm 95$ & $1.64 \pm 0.39$ & $1.90 \pm 0.16$ \\
\hline Monodinium sp. & 1 & $15 \pm 7$ & 0 & $2.10 \pm 0.60$ & 0 \\
\hline Lagynophrya sp. & 3 & $27 \pm 9$ & $74 \pm 49$ & $1.64 \pm 0.39$ & $2.35 \pm 0.71$ \\
\hline
\end{tabular}

\section{Ciliate community structure}

The ciliate assemblage of Lake Søbygård was dominated by typical planktonic species (Foissner 1994), and, despite the mixing of the shallow water column, benthic species (e.g. hypotrichous ciliates) only occurred sporadically in the samples. The high ciliate densities found during our investigation period were well within the range normally observed in this lake, the summer means of previous years were 100 to 300 ciliates $\mathrm{ml}^{-1}$ (Jeppesen et al. 1998), and fit to the generally high abundance of all plankton organisms in this productive system.

Although Lake Søbygård is an extreme habitat with respect to the mixing regime, high nutrient input, primary productivity and concentrations of organisms, it seems that the general composition of the ciliate community during our study period is comparable to other deeper and less eutrophic lakes.

Planktonic ciliate communities of several temperate lakes in central Europe have been recently examined: mesotrophic Lake Constance in southern Germany (Müller 1989), eutrophic Rimov Reservoir in southern Bohemia (Simek et al. 1995, Macek et al. 1996) and oligo-mesotrophic Piburger See in Austria (Sommaruga \& Psenner 1993, Macek et al. 1996). Some characteristic features are that ciliates $<20$ to $30 \mu \mathrm{m}$ numerically dominate and that the major taxa throughout most of the season are small prostomatids (Urotricha spp., Balanion planctonicum) and small oligotrichs (Halteria spp., Strobilidium spp.) whereas bacterivorous Scuticociliates are only temporarily more important.

The dominating taxa in our study, Urotricha, Rimostrombidium (or Strobilidium) and Halteria, were also among the most important ciliate species in the other lake studies. For example, in the Rimov Reservoir (Simek et al. 1995, Macek et al. 1996) the dominant species were also Halteria grandinella, Rimostrombidium brachykinetum (referred to here as Strobilidium hexakinetum) and Urotricha spp.. Further, Cine- tochilum margaritaceum and Cyrtolophosis mucicola occurred in significant numbers in both our study and in the Rimov Reservoir.

The filter-feeding small oligotrichous species, such as Halteria and Strobilidium, have a substantial grazing impact on heterotrophic and autotrophic picoplankton (Simek et al. 1995, Stabell 1996) whereas small prostomatids, as raptorial feeders, can exert significant grazing pressure on nanophytoplankton such as cryptomonads (Müller 1991, Sommaruga \& Psenner 1993) and the grazing activity of these ciliate groups can have a considerable impact on overall fluxes within the pelagic food web (Weisse et al. 1990, Simek et al. 1995).

\section{Zooplankton predation impact}

Our enclosure experiments suggest a strong impact of the metazooplankton on the abundance and community structure of the ciliate assemblage. The shift in zooplankton composition between the 2 experiments, from dominance of rotifers to dominance of cyclopoid copepods, was probably the decisive factor for the nearly 10 -fold reduction in ciliate numbers from the first to the second experimental period. There are several reasons why changes in food supply (bottom-up control) were not responsible for the ciliate community decline. First, total phytoplankton increased from the first to the second period and, although the majority was composed of Scenedesmus colonies, other algae within the edible size range, e.g. cryptomonads, picoalgae and single cells of Scenedesmus, were present in fairly high numbers. Second, ciliates responded immediately to the zooplankton changes in the enclosure experiments, and finally the calculated net growth rates of the dominant species (Table 5) are among the highest values measured for these or related species in field or laboratory experiments (Müller \& Geller 1993, Macek et al. 1996), thus suggesting saturating food conditions. Favourable growth 
conditions for microzooplankton probably prevail during most of the season in Lake Søbygård, as well as in other Danish hypertrophic, shallow lakes, because they are generally dominated by small, edible green algae (e.g. Scenedesmus spp., Chlorella sp.) (Jensen et al. 1994) and not by cyanobacteria (of probably lower food quality) as found in many deeper, hypertrophic lakes (Sommaruga \& Robarts 1997).

Predation rates on different ciliate taxa have been assessed for several metazooplankton groups under defined experimental conditions le.g. Arndt 1993. Gilbert \& Jack 1993, Wiackowski et al. 1994, Wickham 1995). These studies help us interprete the ciliate population dynamics in our experiments. The dominating ciliate species in Lake Søbygård during our experimental period were small-sized forms (15 to $25 \mu \mathrm{m}$ ) which have been shown to be most susceptible to metazooplankton grazers (Jack \& Gilbert 1993, Gilbert \& Jack 1993). Strong differences in the predation efficiency of different zooplankton groups may, however, occur (Wiackowski et al. 1994). This was also evident in our experiments where zooplankton predation pressure on ciliates differed substantially between Expts 1 and 2 .

\section{Expt 1: low predation impact by rotifers}

Although the zooplankton population shift during the first experiment made the interpretation of the trophic interactions more difficult, some clear trends can be deduced from the very different developments in the $+\mathrm{ZP}$ and $<50$ enclosures. Contrary to what might be expected, the total number of small ciliates declined after the removal of zooplankton $>50 \mu \mathrm{m}$ but the 3 dominant small ciliate taxa were affected differently: Rimostrombidium brachykinetum, which had achieved high growth rates in the lake and in the zooplankton enclosures, was entirely suppressed, Halteria declined to lower numbers and Urotricha spp. remained nearly unchanged compared to $+\mathrm{ZP}$. Thus, overall top-down control of small ciliates appeared to increase after the removal of metazooplankton. Potential predators in the $<50$ enclosures were small rotifers (e.g. Filinia) and large, predatory ciliates (e.g. Lagynophrya, Monodinium) which both increased in abundance during the course of the experiment (Fig. 2).

Rotifers are potential predators on ciliates (reviewed by Arndt 1993) and it has been reported that microfiltrating species such as Brachionus, Keratella and Filinia have an impact on small ciliates whereas grasping species such as Asplanchna and Polyarthra will have a higher impact on large ciliate species (Arndt 1993). Gilbert \& Jack (1993) showed that the rotifers Asplanchna girodi, Brachionus calyciflorus and Syn- chaeta pectinata are effective predators of ciliates in the 45 to $60 \mu \mathrm{m}$ size range, ingesting up to 50 ciliates rotifer ${ }^{-1} \mathrm{~d}^{-1}$. The large rotifer community $(>10000$ ind. $\mathrm{l}^{-1}$ ) at the start of the first experiment certainly exerted a substantial grazing pressure on the ciliates. It was probably the reason for only moderate ciliate densities at the beginning of Expt 1 and an increase in ciliates after the collapse of the rotifer community in the lake. However, by assuming ingestion rates to be within the range of 20 to 50 ciliates rotifer ${ }^{-1} \mathrm{~d}^{-1}$ and a ciliate abundance of $300 \mathrm{ml}^{-1}$, the overall grazing rate of 0.7 to $1.7 \mathrm{~d}^{-1}$ is still lower than the growth rates of the dominant ciliate species (Table 5).

It is evident that not all of the small ciliates were affected to the same extent by rotifers, despite only slight differences in body size. Halteria remained at relatively high levels before and after the collapse of the rotifer populations, suggesting only low impact by the rotifers. The jumping response of Halteria is an effective escape mechanism against rotifers (Gilbert 1994). Large ciliates were probably more efficient predators on Halteria as judged from the inverse development of the 2 groups. Rimostrombidium brachykinetum seems to be more vulnerable to predation, both by large rotifers and by predatory ciliates, as indicated by the inverse population development of this species and of rotifers in the lake and the $+\mathrm{ZP}$ enclosures. The smallest of the 3 dominating taxa, Urotricha spp., was obviously least effected by predation as the population developments in the $+\mathrm{ZP}$ and $<50$ treatments did not significantly differ (Fig. 3).

Evidence of the importance of predatory ciliates also comes from the $<10 \mu \mathrm{m}$ fractionations (Fig, 3). Rotifers were not present in these treatments and all small ciliate taxa grew virtually without predation and achieved high population abundances. Later in the experiment large, predatory ciliates (Lagynophrya, Monodinium) appeared and probably caused the decline of the small ciliate species. Again a pronounced effect on Halteria was observed, emphasizing the important role of this predation force within the ciliate community.

In summary, rotifer dominated mesozooplankton seemed to have exerted only a weak top-down control on small ciliates but had an indirect positive influence by controlling predators in the microzooplankton size range. It confirms the general observations that ciliates and rotifers often co-occur in higher numbers in eutrophic lakes (Sommaruga 1995, Jürgens unpubl obs.). A survey on zooplankton from 18 Danish lakes revealed that rotifers were the only zooplankton group which is strongly positively related to abundance and biomass of ciliates (Jeppesen unpubl. data). No or only modest effects of rotifers on planktonic ciliates in field 
experiments were also reported by Jack \& Gilbert (1997) and Havens \& Beaver (1997). Complex interactions within the micro- and nanozooplankton and protozoan predation of other protozoans are typical for situations when large populations of mesozooplankton are absent. Rotifers and ciliates have considerable overlap in their food niches and in addition to direct predation and interference effects, exploitative competition might occur. The fact that rotifers can serve as alternate food sources for cyclopoid copepods (Adrian 1991, Jack \& Gilbert 1997) is another indirect positive effect on ciliates, especially favouring the larger species.

\section{Expt 2: top-down control by cyclopoid copepods and Daphnia}

The second experiment proved to be much clearer with regard to the impact of mesozooplankton on the ciliate community. Initial ciliate densities were about 1 order of magnitude lower than during the first experiment. Only the smallest of the dominant ciliate species, Urotricha spp., was still at moderate densities (25 cells $\mathrm{ml}^{-1}$ ). The immediate response and high net growth rates of all ciliate taxa after removal of zooplankton $>50 \mu \mathrm{m}$ suggest an efficient top-down control on the ciliate community (Fig. 4). The dominating mesozooplankton during this experiment, initially Cyclops vicinus and later Daphnia spp, can both cause significant mortality of planktonic ciliates (Jack \& Gilbert 1993, Wickham 1995).

We suggest, however, that initially the copepods maintained ciliates at low numbers, as the high abundance of phytoplankton (mainly Scenedesmus spp.) indicated that grazing by daphnids was still not pronounced. The selective feeding behaviour of copepods can explain why ciliate numbers declined to low levels while phytoplankton remained rather unaffected. Cyclopoid and calanoid copepods detect their prey mainly by mechanoreception (DeMott \& Watson 1991) which can be used to locate ciliates within dense phytoplankton. Further, some cyclopoid species actively select for motile prey species (Price 1988, DeMott \& Watson 1991). Cyclops vicinus, the dominating copepod species in Lake Søbygård, has not been examined with regard to feeding on ciliates. Its feeding behaviour is, however, rather similar to the omnivorous C. kolensis (Adrian 1991), which has been shown to be an efficient predator of planktonic ciliates (Wickham 1995). Although larger ciliates are generally more effected by Cyclops predation (Wickham 1995, Dobberfuhl et al. 1997), smaller species such as Halteria are also consumed at rates of up to 20-30 ciliates cope$\operatorname{pod}^{-1} \mathrm{~h}^{-1}$ (Wickham 1995).
The predation impact of Daphnia, which increased during the second experiment, affects a wide prey size range and most groups of planktonic protozoans (Jürgens 1994). The ability to suppress ciliate populations is well documented (Pace \& Funke 1991, Jack \& Gilbert 1993, Marchessault \& Mazumder 1997, Pace et al. 1998). The shift from cyclopoids to daphnids even enhances grazing pressure on ciliates and includes the smallest species.

\section{General implications for metazoan-protozoan coupling in lake plankton}

It is evident now that metazooplankton predation is a decisive factor for controlling population sizes and species composition of planktonic protozoans (Sanders \& Wickham 1993). Protozooplankton is generally dominated by small forms $(<30 \mu \mathrm{m}$ in diameter) that are highly vulnerable to zooplankton predation. Zooplankton clearance rates of nanoflagellates resemble those of edible nano-phytoplankton (Carrick et al. 1991, Jürgens et al. 1996). For ciliates, predation vulnerability is taxon-specific for both the predators and prey (Wiackowski et al. 1994). Ciliate behavioural adaptations to lower grazing mortality (e.g. escape response) influence the outcome of the predator-prey interactions. This study and comparable ones performed in other systems reveal the importance of predation by different zooplankton groups (Wiackowski et al. 1994, Marchessault \& Mazumder 1997) but results are to some extent still contradictory (e.g. Havens \& Beaver 1997 ).

The controlling modes and the interactions between microbial and classical food webs can change within short periods of time. Whereas in the second experiment the whole ciliate community was equally effected by zooplankton predation, the first experiment revealed strong differences in the response of the different ciliate species within the same size range.

The planktonic ciliate assemblage reflects the metazooplankton community and its specific predation pressure. This is particularly pronounced in shallow, productive lakes where nutrient constraints are less important and food supply is sufficient to achieve high growth rate and population sizes. In those systems, alterations at the top of the food web propagate to lower trophic levels and affect phyto- and bacterioplankton (Jürgens et al. 1994, Dobberfuhl et al. 1997). The study on ciliate dynamics in Lake Søbygård reveals characteristics which support the overall picture of plankton organisms in shallow hypertrophic systems: top-down control is a dominating structuring force for the biological community and few species oscillate in exceptionally high numbers (Jeppesen et al. 1997). 
Acknowledgements. The assistance of the technical staff of the National Environmental Research Institute, Silkeborg, is gratefully acknowledged. We also thank Wilhelm Foissner for confirming our ciliate identifications and David Montagnes and Helga Müller for comments on an earlier version of the manuscript. Nancy Zehrbach is acknowledged for her linguistic help. K.J. was supported by a DANVIS grant from the Danish Research Academy and E.J. by the Danish Natural Science Research Council (grant 9601711).

\section{LITERATURE CITED}

Adrian R (1991) The feeding behaviour of Cyclops kolensis and $C$. vicinus (Crustacea, Copepoda). Verh Int Verein Limnol 24:2852-2863

Arndt $H$ (1993) Rotifers as predators on components of the microbial web (bacteria, heterotrophic flagellates, ciliates) - a review. Hydrobiologia 255/256:231- 246

Beaver JR, Crisman TL (1982) The trophic response of ciliated protozoans in freshwater lakes. Limnol Oceanogr 27 : $246-253$

Burns CW, Gilbert JJ (1993) Predation on ciliates by freshwater calanoid copepods: rates of predation and relative vulnerabilities of prey. Freshw Biol 30:377-393

Carrick HJ, Fahnenstiel GL, Stoermer EF, Wetzel RG (1991) The importance of zooplankton-protozoan trophic couplings in Lake Michigan. Limnol Oceanogr 36:1335-1345

Carrick HJ, Fahnenstiel GL, Taylor WD (1992) Growth and production of planktonic protozoa in Lake Michigan: in situ versus in vitro comparisons and importance to food web dynamics. Limnol Oceanogr 37:1221-1235

DeMott WR, Watson MD (1991) Remote detection of algae by copepods: responses to algal size, odors and motility. J Plankton Res 13:1203-1222

Dobberfuhl DR, Miller R, Elser JJ (1997) Effects of a cyclopoid copepod (Diacyclops thomasi) on phytoplankton and the microbial food web. Aquat Microb Ecol 12:29-37

Foissner W (1994) Progress in taxonomy of planktonic freshwater ciliates. Mar Microb Food Webs 8:9-35

Foissner W, Blatterer H, Berger H, Kohmann F (1991) Taxonomische und ökologische Revision der Ciliaten des Saprobiensystems - Band I. Cyrtophorida, Oligotrichida, Hypotrichia, Colpodea. Informationsberichte des Bayer Landesamtes für Wasserwirtschaft, Munich, Heft 1/91

Foissner W, Berger H, Kohmann F (1994) Taxonomische und ökologische Revision der Ciliaten des Saprobiensystems-Band III. Hymenostomata, Prostomatida, Nassulida. Informationsberichte des Bayer Landesamtes für Wasserwirtschaft, Munich, Heft 1/94

Foissner W, Blatterer H, Berger H, Kohmann F (1995) Taxonomische und ökologische Revision der Ciliaten des Saprobiensystems - Band IV. Gymnostomatea, Loxodes, Suctoria. Informationsberichte des Bayer Landesamtes für Wasserintschaft, Munich, Left 1/95

Gilbert JJ (1994) Jumping behavior in the oligotrich ciliates Strobilidium velox and Halteria grandinella, and its significance as a defense against rotifer predators. Microb Ecol $27: 189-200$

Gilbert JJ, Jack JD (1993) Rotifers as predators on small ciliates. Hydrobiologia 255-256:247-254

Hansen AM, Jeppesen E (1992) Life cycle of Cyclops vicinus in relation to food availability, predation, diapause and temperature. J Plankton Res 14:591-605

Havens KE, Beaver JR (1997) Consumer vs. resource control of ciliate protozoa in a copepod-dominated subtropical lake. Arch Hydrobiol 140:491-511
Holm-Hansen D, Riemann B (1978) Chlorophyll a determination: improvements in methods. Oikos 30:438-447

Jack JD, Gilbert JJ (1993) Susceptibilities of different-sized ciliates to direct suppression by small and large cladocerans. Freshw Biol 29:19-29

Jack JD, Gilbert JJ (1997) Effects of metazoan predators on ciliates in freshwater plankton communities. J Eukaryot Microbiol 44:194-199

Jensen JP, Jeppesen E, Olrik K, Kristensen P (1994) Impact of nutrients and physical factors on the shift from cyanobacterial to chlorophyte dominance in shallow Danish lakes. Can J Fish Aquat Sci 51:1692-1699

Jeppesen E, Søndergaard M, Sortkjaer O, Mortensen E, Kristensen $P$ (1990) Interactions between phytoplankton, zooplankton and fish in a shallow, hypertrophic lake: a study of phytoplankton collapses in Lake Søbygård, Denmark. Hydrobiologia 191:149-164

Jeppesen E, Søndergaard M, Jensen JP, Mortensen E, Sortkjaer $O$ (1996) Fish-induced changes in zooplankton grazing on phytoplankton and bacterioplankton - a long-term study in shallow hypertrophic Lake Søbygaard. J Plankton Res 18:1605-1625

Jeppesen E, Jensen JP, Søndergaard M, Lauridsen T, Pedersen $L J$, Jensen $L$ (1997) Top-down control in freshwater lakes: the role of nutrient state, submerged macrophytes and water depth. Hydrobiologia 342/343:151-164

Jeppesen $E$, Sandergaard $M$, Jensen JP, Mortensen $E$, Hansen AM, Jørgensen T (1998) Cascading trophic interactions from fish to bacteria and nutrients after reduced sewage loading: an 18 year study of a shallow hypertrophic lake. Ecosystems 1:250-267

Jürgens K (1994) The impact of Daphnia on microbial food webs - a review. Mar Microb Food Webs 8:295-324

Jürgens K, Arndt $H$. Rothhaupt KO (1994) Zooplanktonmediated changes of bacterial community structure. Microb Ecol 27:27-42

Jürgens K, Wickham SA, Rothhaupt KO, Santer B (1996) Feeding rates of macro- and microzooplankton on heterotrophic nanoflagellates. Limnol Oceanogr 41 . 1833-1839

Krainer KH (1995) Taxonomische Untersuchungen an neuen und wenig bekannten planktischen Ciliaten (Protozoa: Ciliophora) aus Baggerseen in Österreich. Lauterbornia 21:39-68

Lampert W (1978) Release of dissolved organic carbon by zooplankton grazing. Limnol Oceanogr 23:831-834

Laybourn-Parry J, Rogerson A (1993) Seasonal patterns of protozooplankton in Lake Windermere, England. Arch Hydrobiol 129:25-43

Macek $M$, Simek $K$, Pernthaler J, Vyhnálek V, Psenner R (1996) Growth rates of dominant planktonic ciliates in two freshwater bodies of different trophic degree. J Plankton Res 18:463-481

Marchessault P, Mazumder A (1997) Grazer and nutrient imparts on enilimnetic ciliate communities. Limnol Oceanogr 42:893-900

Montagnes DJS, Lynn DH (1987) A quantitative protargol stain (QPS) for ciliates: method description and test of its quantitative nature. Mar Microb Food Webs 2:83-93

Montagnes DJS, Lynn DH (1991) Taxonomy of choreotrichs, the major marine planktonic ciliates, with emphasis on the aloricate forms. Mar Microb Food Webs 5:59-74

Müler $H$ (1989) The relative importance of different ciliate taxa in the pelagic food web of Lake Constance. Microb Ecol 18:261-273

Müller H (1991) Pseudobalanion planctonicum (Ciliophora, Prostomatida): ecological significance of an algivorous 
nanociliate in a deep mesoeutrophic lake. J Plankton Res 13:247-262

Müller H, Geller W (1993) Maximum growth rates of aquatic ciliated protozoa: the dependence on body size and temperature reconsidered. Arch Hydrobiol 126:315-327

Müller H, Schöne A, Pinto-Coelho RM, Schweizer A, Weisse $T$ (1991) Seasonal succession of ciliates in Lake Constance. Microb Ecol 21:119-138

Pace ML, Funke E (1991) Regulation of planktonic microbial communities by nutrients and herbivores. Ecology 72 : 904-914

Pace ML, Cole JJ, Carpenter SR (1998) Trophic cascades and compensation-differential responses of microzooplankton in whole-lake experiments. Ecology 79 : $138-152$

Petz W, Foissner W (1992) Morphology and morphogenesis of Strobilidium caudatum (Fromentel), Meseres corlissi n. sp., Halteria grandinella (Müller), and Strombidium rehwaldi n. sp., and a proposed phylogenetic system for oligotrich ciliates (Protozoa, Ciliophora) J Protozool 39 : $159-176$

Price HJ (1988) Feeding mechanisms in marine and freshwater zooplankton. Bull Mar Sci 43:327-343

Rice WR (1989) Analysing tables of statistical tests. Evolution 43:223-225

Ruttner-Kolisko A (1977) The effect of the microsporid Plistophora asperospora on Conochilus unicornis in Lunzer Untersee (LUS). Arch Hydrobiol Beih Ergeb Limnol 8 : $135-137$

Sanders RW, Wickham SA (1993) Planktonic protozoa and metazoa: predation, food quality and population control. Mar Microb Food Webs 7:197-223

Sherr EB, Sherr BF (1987) High rates of consumption of bacteria by pelagic ciliates. Nature 325:710-711

Simek K, Bobkova J, Macek M, Nedoma J, Psenner R (1995) Ciliate grazing on picoplankton in a eutrophic reservoir during the summer phytoplankton maximum: a study at

Editorial responsibility: Karel Simek,

České Budějovice, Czech Republic the species and community level. Limnol Oceanogr 40 : $1077-1090$

Skibbe O (1994) An improved quantitative protargol stain for ciliates and other planktonic protists. Arch Hydrobiol 130: $339-347$

Sommaruga R (1995) Microbial and classical food webs: a visit to a hypertrophic lake. FEMS Microbiol Ecol 17:257-270

Sommaruga $R$, Psenner $R$ (1993) Nanociliates of the order Prostomatida: their relevance in the microbial food web of a mesotrophic lake. Aquat Sci 55:179-187

Sommaruga R, Robarts RD (1997) The significance of autotrophic and heterotrophic picoplankton in hypertrophic ecosystems. FEMS Microbiol Ecol 24:187-200

Sondergaard M, Jeppesen E, Kristensen P, Sortkjaer O (1990) Interactions between sediment and water in a shallow and hypertrophic lake: a study on phytoplankton collapses in Lake Søbygård, Denmark. Hydrobiologia 191:139-148

Stabell T (1996) Ciliate bacterivory in epilimnetic waters. Aquat Microb Ecol 10:265-272

Stoecker DK, Capuzzo JM (1990) Predation on protozoa: its importance to zooplankton. J Plankton Res 12:891-908

Taylor WD, Heynen ML (1987) Seasonal and vertical distribution of Ciliophora in Lake Ontario. Can J Fish Aquat Sci 44:2185-2191

Weisse T, Müller H, Pinto-Coelho RM, Schweizer A, Springmann D, Baldringer G (1990) Response of the microbial loop to the phytoplankton spring bloom in a large prealpine lake. Limnol Oceanogr 35:781-794

Wiackowski K, Brett MT, Goldman CR (1994) Differential effects of zooplankton species on ciliate community structure. Limnol Oceanogr 39:486-492

Wickham SA (1995) Cyclops predation on ciliates: speciesspecific differences and functional responses. J Plankton Res 17:1633-1646

Wilbert N (1986) Beitrag zur Morphologie und Ökologie einiger planktischer Ciliaten aus dem Poppelsdorfer Weiher in Bonn (BRD). Arch Protistenkd 131:59-69

Submitted: April 20,1998; Accepted: August 5, 1998

Proofs received from author(s): March 23, 1999 